UDC 81'42:070.811.111

DOI https://doi.org/10.32841/2409-1154.2020.46-2.43

\author{
Chetverikova O.R., \\ Candidate of Philological Sciences, \\ Associate Professor at the Department of English Philology \\ Izmail State University of Humanities
}

\title{
ADVERTISING COMMUNICATION IN CULTURAL ENVIRONMENT
}

Summary. The article is devoted to the study of the peculiarities of advertising communication in the cultural environment of Southern Bessarabia. The existing approaches to the study of advertising are determined, examples of types of advertising texts and their role in influencing the consciousness of the individual are given. The integration of advertising into the social and cultural environment is carried out through various creolized texts and image advertising, which possess cultural and historical background and contain evaluative elements. It has been emphasized that various forms of cultural content in advertising are embodied through language and non-linguistic means, as the relationship between producer and consumer performs social and communicative function. The presence of cultural realities, symbols and archetypes attract interest in the reported information. The difference between rational and emotionally colored advertising is explained. The special role of web versions of printed publications containing advertising messages is emphasized. The importance of media linguistics as an interdisciplinary humanitarian discipline, which studies the functioning of language in the media in all its manifestations, is outlined. Genre-functional features of the media space make it possible to highlight and distinguish news, advertising and PR-discourse. Consideration of social advertising determines the features of the creative impulse in its production, the presence or absence of manipulative tactics and reflects the interaction between senders and recipients. Examples of image advertising are given and their features are explained. The signs of political advertising of Southern Bessarabia are considered. The content and significance of social advertising and its impact on the feelings and emotions of the target audience, which ensures the attractiveness of goods or services for consumers have been noted. The textual forms of advertising observed in Southern Bessarabia are given. The ways of further research are offered.

Key words: advertising text, communication, cultural environment, media linguistics, symbol, addressee, Southern Bessarabia.

Topicality. Contemporary investigation of advertising has been provided in different directions. It has been based on such approaches as communicative, functional, pragmatic, psycholinguistic; sociolinguistic, linguo-cultural. Advertising communication, being performed in different forms, combines symbols and archetypes, national pictures of the world, mythological elements. Integration into social and cultural environment is carried out by means of different methods, like creolized image advertising, or visual storytelling, which are based on cultural and historical events and contain evaluative elements. Besides, advertising texts and separate slogans, including infographic images, represent information in a concentrated specific form. The following types of advertising attract undivided attention: teaser advertising, which is most often seen on the Internet; advertising posters, animation screensavers, dynamic multi-vector presentations, banner advertising; native advertising as an overview of new brands, products and services. Non-traditional advertising combines a variety of media, from elevators of high-rise buildings to the pets' skin. A separate place is occupied by computer game advertising. Updating and diversifying advertising makes its research quite topical.

Understanding the patterns and features of advertising as a phenomenon of culture becomes a crucial task of modern research. Various forms of cultural content are embodied in advertising through linguistic and extra-linguistic means, since the relationship between the producer and the consumer performs a socio-communicative function. Advertising contains cultural realities, symbols and archetypes, national world pictures, various mythological models. Lingual contacts, experience changes in form and content of virtual and printed social and commercial communication also contribute to the interpenetration of cultures.

Objective. The choice of the research is based on the changes taking place in linguistic science and in the world, and lead to informative updating of communication processes, determine special interest in comprehensive analysis of advertising products presented in the Bessarabian cultural environment, facilitating the identification of more effective approaches to the study of advertising messages from different linguistic angles.

The communicative strategy of an advertising message is intended to persuade the mass audience to buy a product or to accept an advertised offer, so, such a message occupies the primary position on the scale of "message-impact". The ability of an advertising message to have influence on the addressee also depends on the public values and lifestyles. Rational advertising should inform the buyer about the quality of the product, so it contains appeals to his mind, arguments, drawings, drawings, diagrams, photographs. By its nature, it is straightforward, and is designed for instant external effect. Emotional advertising uses linguistic and non-linguistic symbols, moves to deep emotional motives, appeals to the feelings, so it is expressive and emotionally colored.

The work is concentrated on advertising communication in the cultural environment of the Southern Bessarabian territory. It studies various linguistic characteristics of an advertising text as a communicative unit, explains the difficulty of defining and distinguishing between advertising text genres, studies the linguistic features of sender-addresser relations, the factor of gender reflected in advertising, evaluation vocabulary and the linguistic features of the advertising slogan as a small genre text.

Today, the access to collection, processing, storage, and transfer of information has increased in the world. Consequently, we can speak about the increasing influence of the media on the development of various spheres of human activity. There also appeared new forms of communication exchange, development of new information technologies and multimedia tools. Thus, modern society can be defined as a society where we observe constant multiplication, 
acceleration and globalization of information exchange. We have opened another page in the development of public communications, which involves rapid information exchange.

There is a tendency to supplant traditional sources of information by electronic media, and so the study of the Internet versions, caused by the transformation of the traditional media affects the future of the world press. The decline in the popularity of printed media can be explained not only by the access of the press to social networks, but also by the fierce competition in the media market, which is also reflected in advertising business.

The "web-versions" promoted the development of two important strategic principles for the transmission and presentation of general media information: "print-first", when the internet version performs a minor role, serving as an addition to the main printed publication, and "web-first", when the attention is paid to the on-line publications and printed editions remain in the background [1, p. 184].

With the development of public communications, we may observe parallel development of linguistic science that deals with its study. Today, we can speak about the emergence of media linguistics, as a new interdisciplinary humanitarian discipline that deals with the study of the functioning of language in the media. Media linguistics is focused on the aspects, as: the role of media in the development of languages, functional and stylistic status of media broadcasting, the concept of media text as a basic category of media linguistics, description of methods for studying media messages, analysis of printed, electronic, informational, analytical, artistic and advertising texts, investigation of media discourse in the context of intercultural communication and others [2, p. 98].

Distinguishing of media linguistics as an independent science is connected with the study of media texts. Media text thus represents the dialectical unity of linguistic and media features that combine three levels of media broadcasting: verbatim text, video or graphics, and audio [3, p. 38]. Along with the concept of media linguistics, there appear the notions of media space, media product, media format, social network, mass media monitoring, media methodology, media chat, etc.

For the transmission of information in the media network, we take into account linguistic and extralinguistic parameters of information, genre peculiarities and electronic and printed texts. Depending on the genre-functional features of the media space, we may distinguish the following types of media discourse: news, advertising, and promotional discourse (PR), depending on the purpose of presentation - informational, analytical, journalistic, ideological discourse, etc. [4, p. 18].

Advertising is part of the cultural environment, an important factor, shaping the aesthetic consciousness of man. According to O. Yu. Olenina, a certain part of advertising executed on the high professional level can be attributed to the phenomena of artistic culture [5, p. 12].

The anthropocentric approach in scientific research, which has become relevant at the turn of the millennium, made it possible to refer to the language of advertising as a special kind of text, and directed scientific research toward a communicative-discursive approach, made it possible to investigate and identify the essential features of advertising communication as a special kind of human activity. As a rule, advertising communication takes place in a certain society, which has its own peculiar historical and cultural differences, it also implies the presence of a recipient who must interpret the information received. It has varying degrees of influence, formal design, accent differences that need careful study.
Understanding the patterns and features of the functioning of advertising as a phenomenon of culture is a necessary and relevant component of modern spiritual life of man and society. Different forms of cultural content are embodied in advertising through imaginative and expressive means, since the relationship between the producer and the consumer performs a socio-communicative function that manifests itself in the actual space of culture. In the 21 st century, we observe the interpenetration of cultures, and individuals mainly receive information through electronic means and mass communication, thus the form and content of social contacts changes. Advertising texts are constantly integrated into social and cultural processes, so linguistic and cultural orientation of advertising makes it an integral part of public life.

In Ukraine, as well as in other European countries, the ability to create interesting, useful and inspiring stories has always been appreciated. The advertising message in this case broadcasts media stories in which the main character may be the founder of the company or brand, an employee of an enterprise, a consumer of the advertised product or service. For example, "Tabletki.ua book medicines at pharmacies. Save your time and money. Tabletki. ua - book medicines at pharmacies. Save your time and money. With us are already 6000 pharmacies across Ukraine! You can find the right medication at the pharmacy near you and not waste your time and money. Enter the website www.tabletki.ua, enter the name of the drug in the search bar and choose the best price at the pharmacy nearby, save up to 30\% when booking through the site". Furthermore, there goes a story: "Why do we get tired? How do I get back to active status?" with the detailed explanation of different fatigue causes - physiological, psychological, lifestyle and medical.

The successful use of storytelling method arouses interest of the target audience by adding to the story interesting facts that are remembered and attract attention of the audience (if consumers are interested, they will find the hero of the page than the story ends and read the material to the end). Thus, the presentation of advertising and PR content through an interesting story allows us to make the material minimally similar to an advertising text, thus attracting $\mathrm{t}$ attention of the target audience [6, p. 115-116] as in the following example: "There is no snow, but it's cold in the evenings - drip! So, in order not to freeze and then not think what medicine to use for the running nose $c_{\mathrm{C}}$, it is better to choose UFO in time and catch the rays! In our new article we'll talk about the main types of infrared heaters, you'll get acquainted with modern models and get an opportunity to understand the technical characteristics of! Go to http: //bit.ly/2TfquRi $\odot$ )"

Advertising always responds to the requests and moods existing in a society, correlates with the state of its development and standards, seeks to achieve harmony and reflect the views and opinions of readers or viewers. On the other hand, it affects person's values and lifestyle, including his or her mentality.

Considering huge influence of the advertising text on the mental state of an individual, it is necessary to point out the common values of Ukrainian and of course, Bessarabian culture, such as: openness, sincerity, tolerance towards other nationalities, due to geographical location on the territory of Eastern Europe, hopes for the better future, morality, belief in a "miracle", national identity. The cultural environment of the Southern Bessarabia carries out various activities and satisfies cultural, informational and other needs of the society. They cover, in particular, television, radio, print and book production, and the cultural and artistic environment. 
One of the tasks of modern advertising is to transform culture into the most promising source of economic growth and better life quality. Different peoples, in certain historical periods of development, form the cultural forms in which they find the means to meet their own needs. In the information society, advertising has the status of universal means of socio-cultural communication. Advertised products and services influence the target audience through the socialization process by demonstrating certain behavioral patterns and transmitting new knowledge.

Understanding advertising as a phenomenon that has received cultural and creative functions through cultural development emerged in the late twentieth - early XXI century. Therefore, the issue of considering and understanding the phenomenon of advertising as a particular cultural form that has social footprints is quite relevant. The historical development of communication in advertising makes it possible to argue that its genesis has close links with certain socio-cultural qualities that in particular characterize a society.

Advertising is a specific type of activity within which a special kind of texts is being constructed. An advertising text can be presented as a particular cultural form, the role of which is to demonstrate a particular pattern of behavior to which a brand, product, or service can be added. For the promotion of a specific idea, method, model, or "promotion" of a product, teaser advertising may be used. The English word "teaser" means presentation of a very exciting and interesting piece of information without naming, a company, brand or advertised product [7, p. 3-5]. Though there is no mentioning or hinting of the advertised brand, the associative link between the brand name or the advertiser's company and the content can still be traced.

The main purpose of teaser advertising is to separate and distinguish an advertised message from the other advertised products by providing only a portion of the information to the target audience. For example - "Athens residential complex" - a teaser advertisement for those, who is looking for a city accommodation. This form of advertising is mainly noted on the Internet, and it is considered a type of online advertising. Teaser advertising always aims to capture people's attention, surprise, intrigue the addressee and, therefore, force him to remember certain information, make him want to get acquainted with the advertised product in the future, for example: "Bessarabian market; Recreation Base; "Wine drug", cheese and lamb. What will be the first gastro-route in Bessarabia?"

In order to manipulate the addressee's attention, such advertising may contain words such as - "wait, it's the first step, in three days, unbelievable, guess what, etc". When naming a product or company that produces it, the recipient is invited to wait for the full information about a product or service that is being deliberately detained for fueling interest following the saying: "Forbidden fruit is sweeter".

The social component of advertising make the values that define the creative impulse and reflect the interaction between the senders of a message and the recipients. Adding social message to advertising communications affects the feelings and emotions of the target audience, provides attractiveness of goods or services for the consumers $[8, p .8]$.

Mass communication in advertising is a necessary component, because it is only through it that advertisers can ensure their main task - attract the maximum number of buyers to the advertised product or the maximum number of users of the advertised service. The main means of advertising include: television channels, radio, print and online advertising, direct mail (or e-mail advertising), advertising on various Internet sites, outdoor advertising (various types of signboards, stands, visors, installations), which should be "catchy" and memorable.

Then we should mention internal advertising - shelf-talkers, mobile phones, solid posters on a rigid basis (cardboard, plastic), stickers, dispensers, trays for advertising leaflets, exhibition equipment. Working with the press may include news media, news releases, press conferences.

Another variation is image advertising, which only large companies with well-known brands can afford. In Southern Bessarabia we come across image advertisements of such well-known companies as Coca-Cola (Get yours now!), Google (Google Shopping Campaigns), Lego (Rebuild the World), as well as purely Ukrainian advertisements (Nova Poshta: The story of creation of the main express delivery in the country), (To build Amazon in Ukraine: how Rozetka became a marketplace) and many other.

Social advertising presupposes various forms of support in society, thus in the human consciousness it is drawing attention to socially significant problems and gives proposals for the possibility to solve them. The objects of social advertising, in the opinion of M. Demchenko, may include the rights of organizations or citizens including their interests, that are legislatively provided, healthy lifestyle; social protection, prevention of offenses; protection of environment and natural resources, development of culture and art, state programs in the field of health care, education and sport [9, p. 111-112].

Social advertising, as well as commercial advertising, can be distributed anywhere and in any form: in printed and electronic media, through outdoor advertising and on vehicles, on the Internet, in the form of leaflets, etc.

A special place in Bessarabian communicative space is occupied by political advertisements. We consider political advertising as one way of building a candidate's positive image. Political advertisements can have a psychological effect on the addressee. It largely adjusts people's political perceptions and behavior, and therefore its linguistic manifestations are investigated within the framework of linguistic-political science and psycholinguistics, since the information, when affecting human consciousness, influences cognitive, emotional, and behavioral characteristics of the recipient. The purpose of political advertising is to penetrate to the consciousness of different social groups of people. In this case, the impact of such ads must be hidden. The concept of "political manipulation" is the purposeful but covert action of a variety of manipulative methods and techniques, both linguistic and extralinguistic, aimed at adjusting or changing the needs, motives, attitudes, provoke behavior in order to gain or retain power by a particular political force. In political advertising, manipulation is based on the use of various linguistic phenomena. The primary function of a word is submission through feelings, images, and subconscious mind. For the TV political advertising visual political manipulation is crucial, since the bulk of information is acquired by people through a visual channel.

Political advertisements refer to creolized texts because they possess features related to different semiotic systems. Creolized text is a complex textual formation in which verbal and iconic elements constitute one visual, structural, semantic and functional unit, aimed at exerting a comprehensive influence on the recipients [10, p. 301]. Such advertisements may be seen everywhere: in printed papers and in their on-line versions, as banners along the streets and highways, as booklets that penetrate to mailboxes. Usually they com- 
bine a picture of a candidate and his motto, or some words about his plans. Iconic components can carry stand-alone information, or support the textual information, making it more meaningful.

E.E. Anisimova distinguishes the following types of creolized texts depending on the interaction with the non-verbal component, namely:

- texts with zero-creolization (no image is present);

- texts with partial creolization (the verbal part of the text is relatively autonomous, and does not depend on the image, auto-semantic relations are noted between the verbal and the visual components. The non-verbal component supports the verbal part;

- texts that are characterized by complete creolization (the verbal part is dependent on the pictorial parts. The verbal part is oriented towards or refers to the image, the image acts as a mandatory element of the text [11, p. 15].

Textual forms of advertising observed in the Southern Bessarabia combine such speech forms, as: monologue, dialogue and polylogue and are divided into four varieties.

1. A promotional interview is a kind of dialogical conversation. The competent person informs the journalist about the product and its attractive sides, stimulates the interest of consumers to buy the product, to notice it, and convinces to have one.

2. A promotional article describes the main qualities and characteristics of a product, compares it with the other products in a specific manufacturing group, and points out the benefits. It is one of the most common genres of this type.

3. An advertising report creates the promotional image of a product or a service giving an expanded view with the specific environment and outlining strengths. In doing so, the author refers to authoritative sources, taking into account the evaluations of wellknown reputable specialists (film stars, famous sportsmen).

4. Promotional reporting clearly shows the significant strong sides of a product at the expense perceived by the author, who reports about the product and acts as its user/consumer.

Conclusions. Addressability is a very important factor in advertising. In the broad sense, destination to the addressee is an essential condition for communication. Further strategic steps that the sender will depend on that. A collective author envisages a range of subjects, such as designers, advertising professionals, marketers, etc., who play an important role in the creation of ads. Effective speech impact of an advertising text signifies correct understanding of the target audience, so determining the linguistic designation of the sender and recipient is very relevant. The effectiveness of the advertising impact depends on the strategic approach and social, gender, psychological, age and other factors, such as the degree of the addressee's educational level, range of interests, degree of trust in the advertiser, religious or political leanings, personal interests, objective and subjective characteristics of the advertised product. The linguistic manifestations of effective advertising need further investigation.

\section{References:}

1. Интернет-СМИ: Теория и практика: учебное пособие для студентов вузов / под ред. М.М. Лукиной. Москва : Аспект Пресс, 2010. $348 \mathrm{c}$

2. Шевченко І.С. Когнітивно-прагматичні дослідження дискурсу. Дискурс як когнітивно-комунікативний феномен : монографія / під заг. ред І.С. Шевченко. Харків : Константа, 2005. С. 105-117.

3. Тертычный А.А. Жанры периодической печати : учебное пособие для вузов. Москва : Аспект Пресс, 2000. 312 с.
4. Лютянська Н.I. Мас-медійний дискурс: типологічні та структурно-організаційні особливості. Серія «Філологічні науки». Ніжин : Ніжинський державний університет ім. Миколи Гоголя, 2014. C. 136-142.

5. Оленіна О.Ю. Реклама як явище художньої культури : автореф. дис. ... канд. мистецтвознав. : 17.00.01. Харків : Харківська державна академія культури, 1998. 19 с.

6. Яненко Я.В. Сучасні рекламні комунікації як чинник соціалізації: монографія. Суми : Сумський державний університет, 2018. 300 с.

7. Trehan K., Maan G.S. Teaser Campaigns: An effective advertising execution for varied goods, services and ideas. Journal of Mass Communication \& Journalism. 2012. Vol. 2. Iss. 11. P. 3-5.

8. Яненко Я.В. Ціннісні пріоритети української реклами у XXI ст. Соціально-гуманітарні аспекти розвитку сучасного суспільства : збірник матеріалів Всеукраїнської наукової конференції : у 3 т. Суми : Сумський державний університет, 2013. Т. 3. С. 116-117.

9. Демченко М. Місце сучасної реклами у системі новітніх соціальних комунікацій. Теле- та радіожурналістика. 2012. Вип. 11. С. 111-116.

10. Тельминов Г.Н. Интернет-реклама как вид креолизованного текста. Вестник ННГУ. 2009. № 5. С. 300-304. URL: https://cyberleninka.ru/ article/n/internet-reklama-kak-vid-kreolizovannogo-teksta.

11. Анісимова Е.Е. Лінгвистика тексту та міжкультурна комунікація (на матеріалі креолізованих текстів). Москва : Академія, 2003. $128 \mathrm{c}$.

Четверікова О. Р. Рекламна комунікація в культурному середовищі

Анотація. Статтю присвячено дослідженню особливостей рекламної комунікації в культурному середовищі Південної Бессарабії. Визначено наявні підходи до вивчення реклами, наведено приклади різновидів рекламних текстів і їх ролі при впливі на свідомість особистості. Інтеграція реклами в соціальне та культурне середовище здійснюється за допомогою різних форм креолізованої та іміджевої реклами, які базуються на культурно-історичних подіях і містять оцінні елементи. Підкреслюється, що різні форми культурного змісту в рекламі втілено за допомогою мовних і позамовних засобів, оскільки відносини між виробником і споживачем виконують соціально-комунікативну функцію. Наявність культурних реалій, символів та архетипів сприяє приверненню інтересу до повідомлюваної інформації. Пояснено різницю між раціональною та емоційно-забарвленою рекламою. Підкреслено особливу роль веб-версій друкованих видань, що містять рекламні повідомлення. Окреслено значення медіалінгвістики як такої міждисциплінарної гуманітарної дисципліни, що займається вивченням функціонування мови в ЗМІ в усіляких іiі проявах. Жанрово-функціональні особливості медіа-простору дають можливість виділити й розрізнити новини, рекламу та PR-дискурс. Розгляд соціальної реклами визначає особливості творчого імпульсу при ії створенні, наявність чи відсутність маніпулятивних тактик і відображає взаємодію між відправниками повідомлення та одержувачами. Наведено приклади іміджевої реклами й пояснено іiї значення. Розглянуто особливості політичної реклами південної Бессарабії. Висвітлено зміст та окремі риси соціальної реклами, іiі вплив на почуття й емоції цільової аудиторії, що забезпечує привабливість товарів чи послуг для споживачів. Наведено текстові форми реклами, що спостерігаються в Південній Бессарабії. Запропоновано шляхи подальшого дослідження.

Ключові слова: рекламний текст, комунікація, культурне середовище, медіалінгвістика, символ, адресат, Південна Бессарабія. 